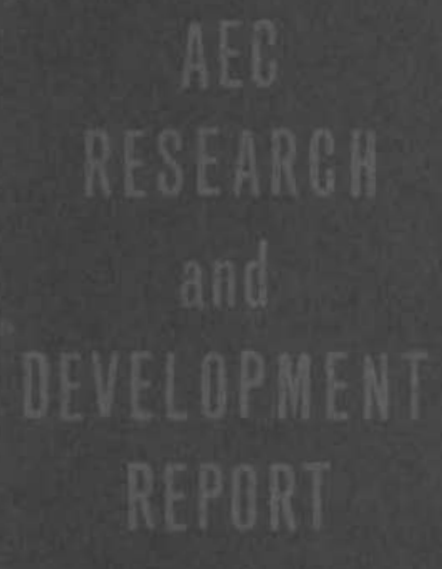

\title{
QUARTERLY PROGRESS REPORT RESEARCH AND DEVELOPMENT ACTIVITIES FIXATION OF RADIOACTIVE RESIDUES JANUARY-MARCH, 1966
}

A. M. Platt

May, 1966

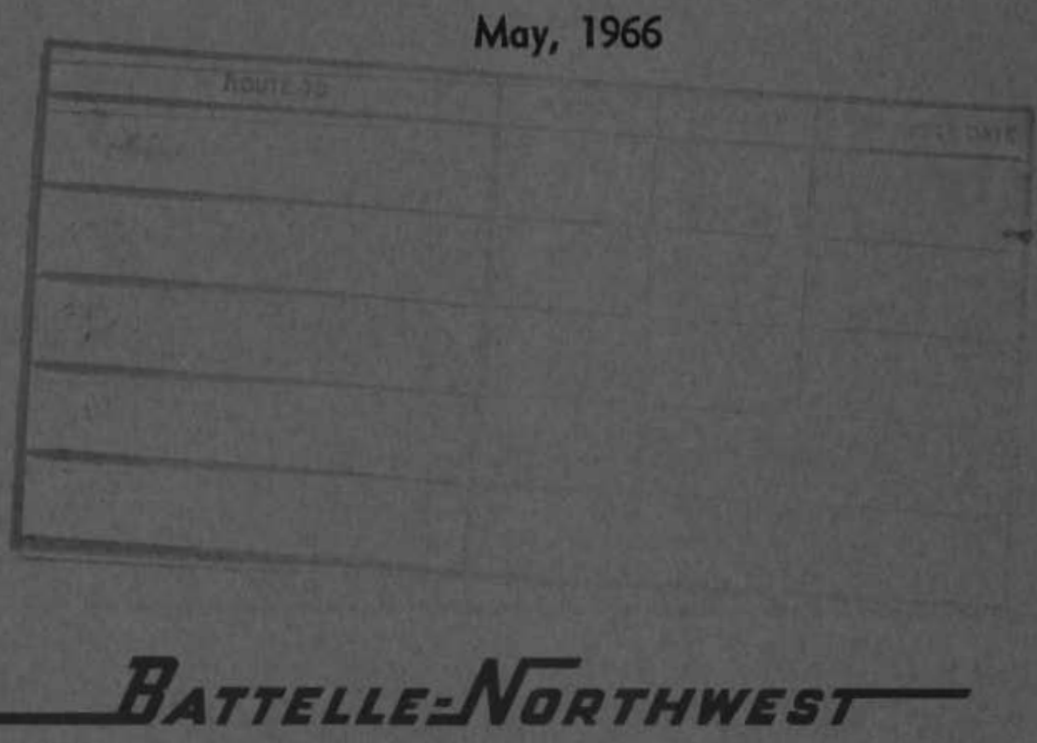

BATTELLE MEMORIAL INSTITUTE / PACIFIC NORTHWEST LABORATORY 


\title{
LEGAL NOTICE
}

This report was prepared as an account of Government sponsored work. Neither the United States, nor the Commission, nor any person acting on behalf of the Commission:

A. Makes any warranty or representation, expressed or implied, with respect to the accuracy, completeness, or usefulness of the information contoined in this report, or that the use of any information, apparatus, method, or process disclosed in this report may not infringe privately owned rights; or

B. Assumes any liabilities with respect to the use of, or for damages resulting from the use of any information, apparatus, method, or process disclosed in this report.

As used in the above, "person acting on behalf of the Commission" includes any employee or contractor of the Commission, or employee of such contractor, to the extent that such employee or contractor of the. Commission, or employee of such contractor prepares, disseminates, or provides access to, any information pursuant to his employment or contract with the Commission, or his employment with such cantractor.

\author{
PACIFIC NORTHWEST LABORATORY \\ RICHLAND, WASHINGTON \\ operated by \\ BATTELLE MEMORIAL INSTITUTE
}

for the

UNITED STATES ATOMIC ENERGY COMMISSION UNDER CONTRACT AT(45-1)-1830 


$$
\begin{gathered}
\text { BNWL-267 } \\
\text { UC-70, Waste Disposal } \\
\text { and Processing }
\end{gathered}
$$

\author{
QUARTERLY PROGRESS REPORT \\ RESEARCH AND DEVELOPMENT ACTIVITIES \\ FIXATION OF RADIOACTIVE RESIDUES \\ JANUARY - MARCH , 1966
}

\begin{abstract}
By
Members of the Staff

Chemistry Department
\end{abstract}

Edited by

A. M. P1att

Chemical Development Section

May, 1966

PACIFIC NORTHWEST LABORATORY

RICHLAND, WASHINGTON 
Printed in USA. Price $\$ 2.00$. Available from the clearinghouse for Federal Scientific and Technical Information Nationa 1 Bureau of Standards

U.S. Department of Commerce Springfield, Virginia 


\section{PREVIOUS QUARTERLY REPORTS}

\begin{tabular}{|c|c|c|c|}
\hline Quarter & Year & Report Number & $\underline{\text { Reference }}^{*}$ \\
\hline & 1959 & & \\
\hline First & & $\mathrm{HW}-60584$ & $59-1$ \\
\hline Second & & $H W-61635$ & $59-2$ \\
\hline Third & & $\mathrm{HW}-63048$ & $59-3$ \\
\hline Fourth & & $\mathrm{HW}-63949$ & 59-4 \\
\hline & 1960 & & \\
\hline First & & $\mathrm{HW}-65209$ & $60-1$ \\
\hline Second & & $\mathrm{HW}-66571$ & $60-2$ \\
\hline Third & & $\mathrm{HW}-67334$ & $60-3$ \\
\hline Fourth & & $\mathrm{HW}-68193$ & $60-4$ \\
\hline & 1961 & & \\
\hline First & & $\mathrm{HW}-69176$ & $61-1$ \\
\hline Second & & $\mathrm{HW}=70517$ & $61-2$ \\
\hline Third & & $\mathrm{HW}-71374$ & $61-3$ \\
\hline Fourth & & $\mathrm{HW}-72324$ & $61-4$ \\
\hline & 1962 & & \\
\hline First & & $\mathrm{HW}-73412$ & $62-1$ \\
\hline Second & & $\mathrm{HW}-74375$ & $62-2$ \\
\hline Third & & $\mathrm{HW}-75290$ & $62-3$ \\
\hline Fourth & & $\mathrm{HW}-76262$ & $62-4$ \\
\hline & 1963 & & \\
\hline Fixst & & $\mathrm{HW}-77299$ & $63-1$ \\
\hline Second & & $\mathrm{HW}-78188$ & $63-2$ \\
\hline Third & & $\mathrm{HW}-79140$ & $63-3$ \\
\hline Fourth & & $\mathrm{HW}-80526$ & $63-4$ \\
\hline & 1964 & & \\
\hline First & & HW- 81862 & $64-1$ \\
\hline Second & & $\mathrm{HW}-83320$ & $64-2$ \\
\hline Third & & $\mathrm{HW}-8446 ?$ & $64-3$ \\
\hline Fourth & & $\mathrm{HW}-84603$ & $64-4$ \\
\hline & 1965 & & \\
\hline First & & BNWL -76 & $65-1$ \\
\hline Second & & BNWL - 139 & $65-2$ \\
\hline Third & & BNWL - 170 & $65-3$ \\
\hline Fourth & & BNWL - 213 & $65-4$ \\
\hline
\end{tabular}

* Reference notation used in this report 
4

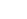

, 1 
$\underline{\text { TABLE OF CONTENTS }}$

\section{INTRODUCTION}

SUMMARY

CALCINATION AND SOLIDIFICATION STUDIES

R. E. Burns, C. R. Cooley, R. L. Moore . . . . 4

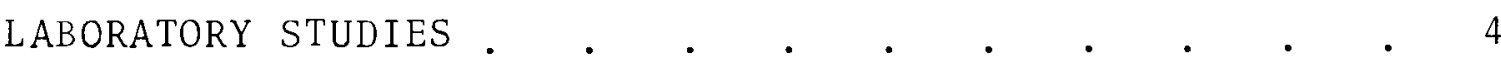

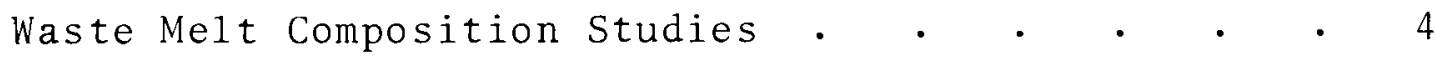

Effects of Variation in Concentration of

Purex Waste Composition on Melt Properties

G. B. Barton . • • • • • • • • • 4

Properties of Melts in the $\mathrm{PW}-1: \mathrm{Na}_{2} \mathrm{O}: \mathrm{P}_{2} \mathrm{O}_{5}$
System - J. E. Mendel . . . 5

Properties of Melts Containing $\mathrm{PW}-2$ Waste
and Additives - J. E. Mendel
.

Thermal Analytical System - G. B. Barton. . . . 6

WASTE SOLIDIFICATION ENGINEERING PROTOTYPES -

J. M. Atwood, C. R. Cooley, J. C. Spanner • • • 8

Prototypes Status - K. J. Schneider, George Rey,

M. O. Rankin, V. P. Kelly • • • • • • 8

Wiped Film Evaporator - M. E. Spaeth. • . . $\quad 8$

Thermal Conductivity and Furnace Heat Tests -

W. V. DeMier. $• \quad \cdot \quad \cdot \quad \cdot \quad \cdot \quad \cdot \quad \cdot \quad \cdot \quad \cdot 9$

Pot Wall Thickness Tester - B. E. Dozer*. . . . 9

WSEP Transfer Cask - M. E. Spaeth . . . . . 10

WSEP Transfer Cask Instrumentation - O. H. Koski. . 14

HAZARDS OF SHIPPING SOLIDIFIED HIGH LEVEL WASTE -

A. E. Albrethsen and L. C. Schwendiman . . . . 14

* Testing Methods, Physics $\mathcal{G}$ Instruments Department 
WASTE SOLIDIFICATION CONDENSATE TREATMENT - G. J. Alkire • 17

Scavenging Mechanisms - C. J. Touhill • • . . 17

Scavenging of Fission Products - C. J. Touhill and

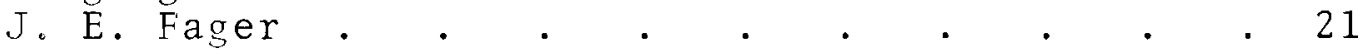

Crystallization of Sodium Sulfate - B. W. Mercer and

C. J. Sroboda. . . . . . . . . . 23

WASTE MANAGEMENT (Not charged to Division of Reactor

Development and Technology). . . . 23

In-Tank Waste Solidification - Jim Dunn and

E. E. Hoar . . . . . . . . . . . 23

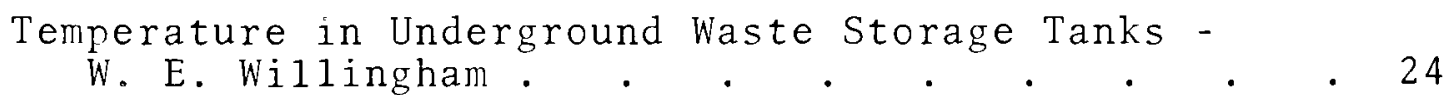

Residual Sludge Detector for Waste Storage Tanks -

C. E. Huck . . . . . . . . . 25

Strontium and Rare Earth Recovery from Zirflex Waste -

G. L. Richardson. . . . . . . . 25

Cesium Ion Exchange Resin Level Measurement -

O. H. Koski . . . . . . . . . . 26 


\author{
QUARTERLY PROGRESS REPORT \\ RESEARCH AND DEVELOPMENT ACTIVITIES \\ FIXATION OF RADIOACTIVE RESIDUES \\ JANUARY-MARCH, 1966
}

\title{
$\underline{\text { INTRODUCTION }}$
}

This progress report is the twenty-ninth in a series presenting research and development activities in the field of radioactive wastes.

Experimental work charged to programs other than those of the Division of Reactor Development and Technology is sometimes included for general interest and completeness; such work is identified in the headings.

\section{SUMMARY}

A survey of properties of melts and solid products in the system $\mathrm{PW}-1$ waste- $\mathrm{Na}_{2} \mathrm{O}-\mathrm{P}_{2} \mathrm{O}_{5}$ was made. The data obtained aided in defining flowsheets for spray calciner-melter processing of PW-1 waste with and without addition of melting-temperaturelowering constituents to the melter.

A statistical study of the effects of variation in composition of a Purex-type waste has been completed but the data are only partially analyzed at present.

A thermoanalytical system has been acquired and partially tested. It will be used primarily for a study of thermal expansion of various solids.

A11 major Waste Solidification Engineering Prototype equipment has been installed in the Chemical and Materials Engineering Laboratory. Instaliation of services is $80 \%$ complete and preliminary equipment tests are underway. 
The mechanically-wiped film evaporator worked well in tests using simulated Purex wastes with added phosphate.

Experiments to examine heat loss mechanisms in Rack $6 \mathrm{~A}$ resistance furnace were completed.

The ultrasonic tester for pot wall thickness has been developed and is ready for field tests.

Heat tests with the 1 iquid transfer casks indicate that the cask can tolerate normal Purex wastes without cooling for greater than eight hours.

A new readout system was developed for use with capacitance probes to measure 1 iquid level in waste casks.

Fission product release studies involving simulated high level ceramic wastes were extended to include samples of phosphate ceramic prepared from actual high level waste. Release rates at $1100^{\circ} \mathrm{C}$ for $\mathrm{Cs}^{137}$ were found to be about $1 \%$ per hour. Releases of $\mathrm{Ru}^{106}$ and $\mathrm{Sr}^{90}$ were measured.

Studies on precipitation-scavenging indicate that ion exchange in the diffuse double layer, chemisorption or both are the principle mechanisms whereby ions are sorbed. Furthermore these mechanisms are related directly to the degree of crystallinity of the adsorbent.

A mixture of hydrous ferric oxide, hydrous manganese dioxide and nickel ferricyanide scavenged greater than $98.5 \%$ $\mathrm{Ru}^{106}, \mathrm{Ce}^{144}, \mathrm{Cs}^{137}, \mathrm{Sr}^{85}$ and $\mathrm{Co}^{60}$ from a simulated glass melter condensate.

High temperature $\left(100^{\circ} \mathrm{C}\right)$ sodium sulfate crystallization experiments show that about $50 \%$ of the strontium from a glass melter condensate remains with the sodium sulfate. 
Plugging of the prototype immersion heater-circulator in plant tests resulted in an expedited experimental investigation of the causes, and the development of instrumentation for, detecting flow in the circulator.

An empirical correlation was developed relating maximum temperature in waste storage tanks to thermal conductivities and thicknesses of the salt cake and soil cover.

Scintillation measurements with a prototype detector indicates this system can indicate sludge deposits in waste storage tanks.

Quantitative extraction of strontium and rare earths from a Zirflex-type waste were achieved with D2EHPA solvent in pulse column studies.

Two techniques for measuring ion exchange resin level are being developed. 


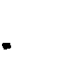


CALCINATION AND SOLIDIFICATION STUDIES

(R. E. Burns, C. R. Cooley, R. L. Moore)

\section{LABORATORY STUDIES}

Waste Melt Composition Studies

Effects of Variation in Concentration of Purex Waste Composition on Melt Properties - G. B. Barton

Since it is known that considerable variation in the concentration of the Purex process cationic constituents - sodium, iron, aluminum, chromium and nickel - occurs, a statistically designed series of experiments was carried out to learn how the variation in individual element concentration affects the properties of the resulting solids.

The solution chosen as nominally representative of the Purex process contained the major process elements at concentrations corresponding to that projected for the original process demonstration in WSEP. Then upper and lower concentration levels were estimated from various flowsheet and analytical data. The final system was:

Leve 1

\begin{tabular}{|c|c|c|c|c|}
\hline \multirow{2}{*}{$\frac{\text { Variable }}{\mathrm{Na}}$} & \multirow{2}{*}{$\frac{\text { Lower }}{0.45}$} & \multirow{2}{*}{$\frac{\text { Center }}{0.70}$} & \multicolumn{2}{|c|}{ Upper } \\
\hline & & & 0.95 & eq/ 1 \\
\hline Al & 0.09 & 0.24 & 0.39 & $\mathrm{eq} / 1$ \\
\hline $\mathrm{Fe}$ & 0.18 & 0.48 & 0.78 & $\mathrm{eq} / 1$ \\
\hline $\mathrm{Cr}+\mathrm{Ni}(2: 1)$ & 0.048 & 0.128 & 0.208 & $\mathrm{eq} / 1$ \\
\hline FP & 10 & 35 & 60 & $\begin{array}{l}\text { wt } \% \text { of ini- } \\
\text { tial oxides }\end{array}$ \\
\hline Nominal Fuel & Exposure (836) & 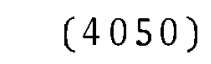 & $(11,290)$ & $\mathrm{MWd} / \mathrm{MT}$ \\
\hline $\mathrm{M} / \mathrm{P}$ & 2.5 & 2.1 & 1.7 & \\
\hline
\end{tabular}


The design called for 48 "off center" points and six replicates at the center composition making a total of 54 . Two heat treatments were used.

The data are currently being analyzed and will be published in a topical report.

Properties of Melts in the PW-1:Na $2 \underline{\mathrm{O}}_{\mathrm{O}} \mathrm{P}_{2}{ }_{2}{ }_{5}$ System -

A series of 49 melts in the $\mathrm{PW}-1$ waste - $\mathrm{Na}_{2} \mathrm{O}-\mathrm{P}_{2} \mathrm{O}_{5}$ system were prepared to aid in choosing optimum spray calcinermelter flowsheet conditions. Composition and melting point of these are shown in Figure 1 . Melts having $M / P$ ratios less than 1.5 were glasses; those with $M / P$ between 1.5 and 2.3 were microcrystalline with some glassy portions if quenched rapidly; those with $M / P$ greater than 2,3 were all microcrystalline.

Two modes of operating the spray calciner-melter system were considered. In the first, no addition of me1t-temperaturelowering constituents is made to the melter; stainless steel receiver pots are required for the relatively high melting temperature melts produced. In the second, melt-temperature-1owering constituents are added to the melter; mild steel receiver pots may be used for the relatively low melting temperature melts produced.

For the first mode, the area bounded by the dark 1 ine in the upper right hand portion of Figure 1 represents the composition range which can be considered. The $\mathrm{P}_{2} \mathrm{O}_{5}$-and $\mathrm{Na}_{2} \mathrm{O}$-rich limits are imposed by operating characteristics of the spray calciner; the PW-1-rich 1 imit is imposed by temperature limitations in the melter and receiver pot. To produce melts having the minimum melting point in this composition range $\left(900^{\circ} \mathrm{C}\right)$ using $\mathrm{PW}-1$ at $100 \mathrm{gal} / \mathrm{tonne} \mathrm{U}$ as feed, it is necessary to make the $\mathrm{PW}-1$ 1.60M in phosphate and $0.75 \mathrm{M}$ in sodium. 
Low-me1ting products which may possibly be collected in mild steel receiver pots can be produced by adding melt-temperature-lowering constituents (such as $\mathrm{NaPO}_{3}$ ) directly to the melter. Products having melt points of $750^{\circ} \mathrm{C}$ or less are required for satisfactory filling of mild steel receiver pots. Corrosion rates for mild steel in some of the candidate melts ranged from 25 to $45 \mathrm{mils} / \mathrm{day}$ at $720^{\circ} \mathrm{C}$ (a temperature at which the melts would just flow). These melts contained 4.6 - 7.5M phosphate and $5.4-7.2 \mathrm{M}$ sodium (PW-1 at $100 \mathrm{gal} /$ tonne U basis). The solid products from these melts were 5 - 10 times more water soluble than the higher melting temperature products described in the preceding paragraph. Also, they contain much less waste oxide - 20 vs. 45-50 wt. $\frac{\circ}{0}$. $\frac{\text { Properties of Melts Containing PW-2 Waste and Additivies - }}{\text { J. E. Mendel }}$

A statistically designed experiment, to define the effects of 1 ithium, calcium, sodium, aluminum and phosphate as additives to $\mathrm{PW}-2$ waste, was completed and the results are being analyzed. The output of the statistical experiment was three equations which express sulfate retention, drip point and solubility as a as a function of additive concentrations. Contour plots are being prepared to aid in final analysis of the results.

Thermal Analytical System - G. B. Barton

A thermoanalytical system has been acquired to permit measurement of thermal expansion, thermogravimetric changes, and direct calorimetry. It is to be first applied to the thermal expansion of various solids. This is one of the areas of concern since a solid that does not shrink as much as the container will cause stress generation. 


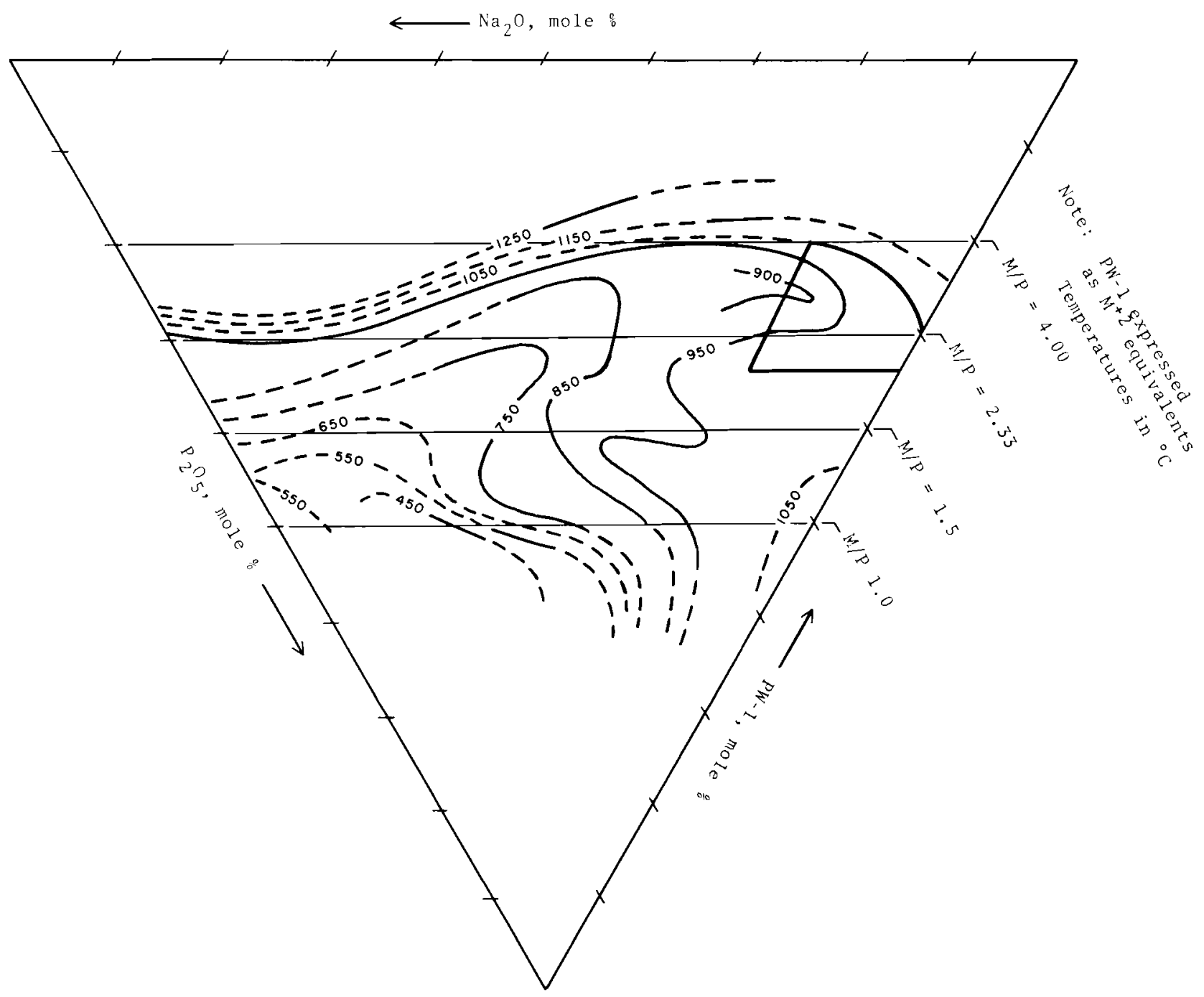

FIGURE 1. $\mathrm{Na}_{2} \mathrm{O}: \mathrm{PW}-1: \mathrm{P}_{2} \mathrm{O}_{5}$ Melting Point Isotherms 
WASTE SOLIDIFICATION ENGINEERING PROTOTYPES

(J. M. Atwood, C. R. Cooley, J. C. Spanner)

$\underline{\text { PROTOTYPE STATUS }}$ - K. J. Schneider, George Rey, M. O. Rankin and V.P. Kelly

Installation of WSEP related equipment has continued. Installation of major equipment was completed, and primary emphasis has been on installation of electrical service, electrical and instrument wiring, in-cell piping jumpers, and outof-cell piping services. Overall completion of the instrumentelectrical and piping services is 75 and $95 \%$, respectively. Overall completion of in-cell piping jumpers is $95 \%$ complete.

The resistance-heated annealing furnace (Rack 6A) was checked out operationally. The induction-heated annealing furnace (Rack 5A), and the welding station (Rack 7B) have been installed and are now being checked out operationally. Remotability testing of equipment has been started. The final process off-gas filtration and pumping system has been installed and is now being checked out. The digital computer has been installed and wiring to it is about $90 \%$ complete.

The C-MEL building was completely released for occupancy on March 1, with a few final items to be done by the contractor on a call-in basis. Subsequent building efforts by plant forces have been concentrated on detailed check-out of the ventilation system, and final preparations for receiving radioactive waste in the building. The tank vault storage system and load-out station have been installed and are being checked out. WIPED FILM EVAPORATOR - M. E. Spaeth

The wiped film evaporator is an alternate concentrator for use in the WSEP. The evaporator can be used to concentrate incoming wastes by about a factor of five (5) (PW-1, PW-2, etc.) and then 
feed a solidification process. The wiped film evaporator is being tested for capacity, deentrainment factor, operability and denitration using simulated wastes.

An eight-hour shakedown run and a 40 hr run were made using simulated Purex $\mathrm{PW}-2$ type waste $\left(\mathrm{M}^{+} / \mathrm{P}=0.96\right.$ and $\left.\left[\mathrm{PO}_{4} \equiv\right]=2.77 \underline{\mathrm{M}}\right)$. Satisfactory operation was obtained with concentration factors of about 3.5 at a feed rate of 43 1iters/hr using a steam pressure of $85 \mathrm{psig.} \mathrm{Preliminary} \mathrm{analytical} \mathrm{results} \mathrm{show} \mathrm{the}$ deentrainment factor to be about $10^{4}$ and denitration to be about $85 \%$ (at concentration factor of 3.5). Following the $40 \mathrm{hr}$ run, visual inspection of the evaporator interior showed it to have a very thin white scale on the deentrainment baffles and bolts on the wiper blades. All other surfaces were quite clean. THERMAL CONDUCTIVITY AND FURNACE HEAT TESTS - W. V. DeMier

Tests to determine heat loss mechanisms on the six-zone resistance furnace were completed and analysis of the data from the tests is underway. The tests are intended to provide a basis for estimating the pot-cooling performance of the furnace. At steady-state operation, heat losses of $6 \mathrm{~kW}$ each were measured from top and bottom zones. Heat loss from remaining zones totalled $19 \mathrm{kw}$. The maximum temperature observed at the furnace outer shell was $175^{\circ} \mathrm{C}$. Inner furnace wall temperature was $800^{\circ} \mathrm{C}$.

Cooling characteristics of the furnace were examined by use of a resistance-heated dummy pot to simulate a pot generating heat by radioactive decay. System temperatures were measured at steady-state for various simulated heat generation rates with cooling air rates of $80 \mathrm{scfm}$ per zone. With a pot heat generation rate of $6200 \mathrm{~W}$, no power to the furnace, and $80 \mathrm{scfm}$ cooling air flow rate, the pot wall temperature was $\sim 250^{\circ} \mathrm{C}$. Heat balance calculations showed $94 \%$ of the input heat was removed by the cooling air. Temperature limitations on the heaters in the resistance-heated pot prevented tests at higher heat generation rates. 
POT WALL THICKNESS TESTER - B. E. Dozer

An ultrasonic pot wall thickness tester has been developed to asses corrosion damage caused by solidivying wastes in a pot. The tester measures wall thickness using the pulse-echo method by measuring the time between the fron and back surface reflections from the pot wall.

The ultrasonic equipment was installed and tested using a 12 in. diam filled pot. The welding machine successfully rotated the pot while a vertical drive mechanism moved the ultrasonic transducer the length of the vessel. Satisfactory wall thickness results were obtained but transducer alignment problems necessitated redesign of the transducer holder. Further tests have been curtailed pending completion of installation of the welding mechanism in the cell.

WSEP TRANSFER CASK - M. E. Spaeth

Two shipping casks (Figure 2) will be used to ship liquid wastes to and from the WSEP. The casks are spherical in shape (75 in. OD) and have a hollow interior ( 55.5 in.. ID). The inner ( $3 / 4$ in. thick) and outer ( 1 in. thick) spheres are made of $304-\mathrm{L}$ stainless steel with eight (8) in. of lead shielding (cast slowly for good bonding). The inner sphere is wrapped with $1 / 2 \mathrm{in.}$ OD $x 0.035$ in. wall stainless steel tubing with a spacing of approximately $1-7 / 8$ in. The outer sphere is equipped with lifting ears and a support pallet made of stainless steel.

The cask is equipped with a series of lines for filling, emptying and venting, etc. All are made of stainless steel pipe which passes through the shielding from the top-wells to the inner sphere. All connections terminate in one of two recessed wells. The smaller well contains only the vent line and the vent valve. The other contains all of the empty and fill connections. It also contains a one-inch vertical opening filter with a capacitance liquid level probe and another normally plugged 1 in. 
opening for a spare. The wells are covered by hinged lids which are sealed by 0 -ring gaskets. For shipment the two 1 ids are covered by an additional stainless steel cap.

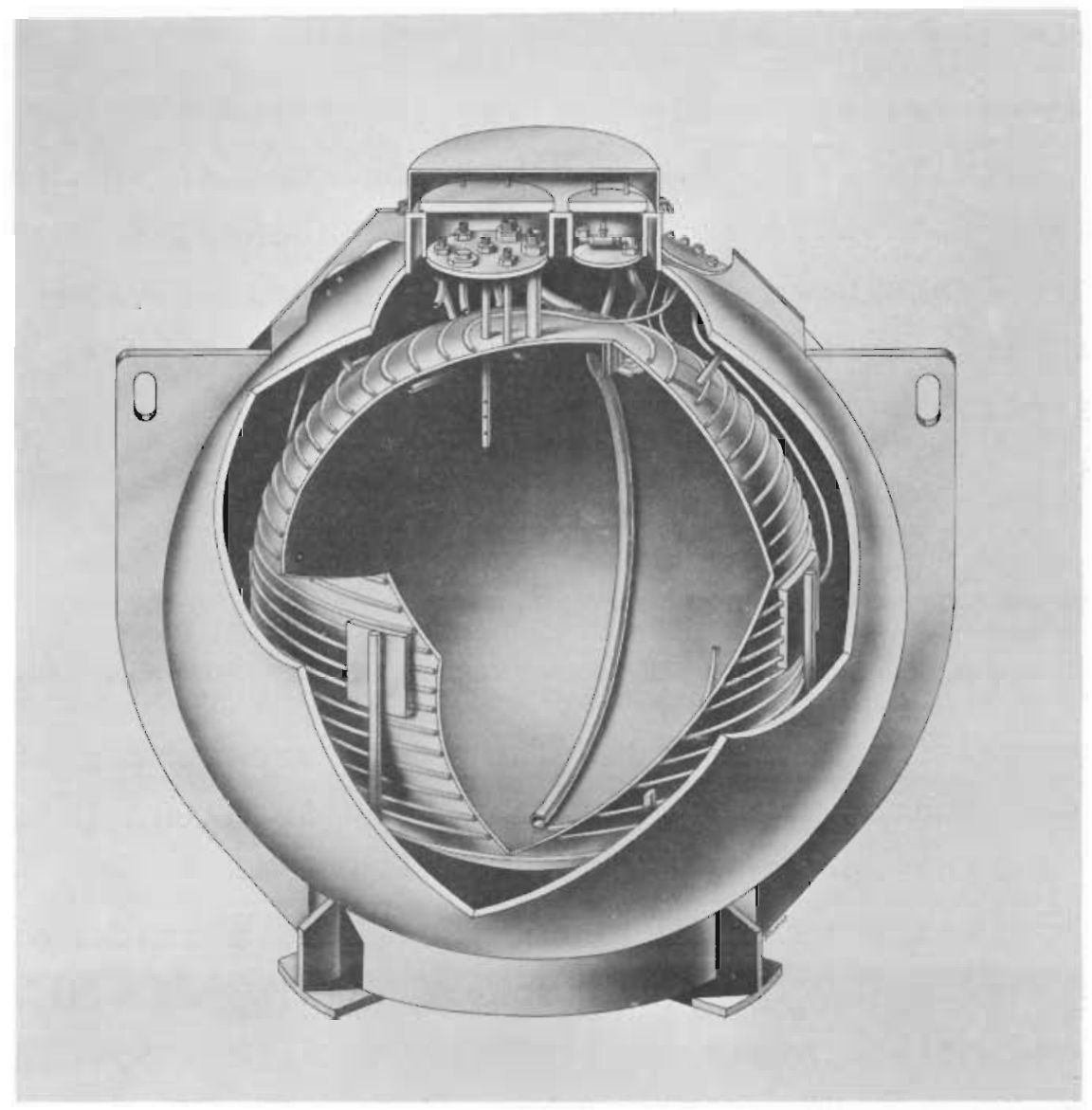

FIGURE 2. 30 Ton Liquid Shipping Cask

other auxiliaries include cooling water and temperature connections on the outside sphere. Two thermocouple probes are provided. One thermocouple measures the inner sphere temperature and the other measures the temperature one inch inside the outer sphere.

Heating tests were made on one of the casks to determine the actual heat transfer characteristics of the casks. The results of the tests are given in Figures 3 and 4 . 
The results show that without auxiliary cooling, and at a heat input estimated as equivalent to Purex waste, the cask contents require about $16 \mathrm{hr}$ to heat from 125 to $2000 \mathrm{~F}$.

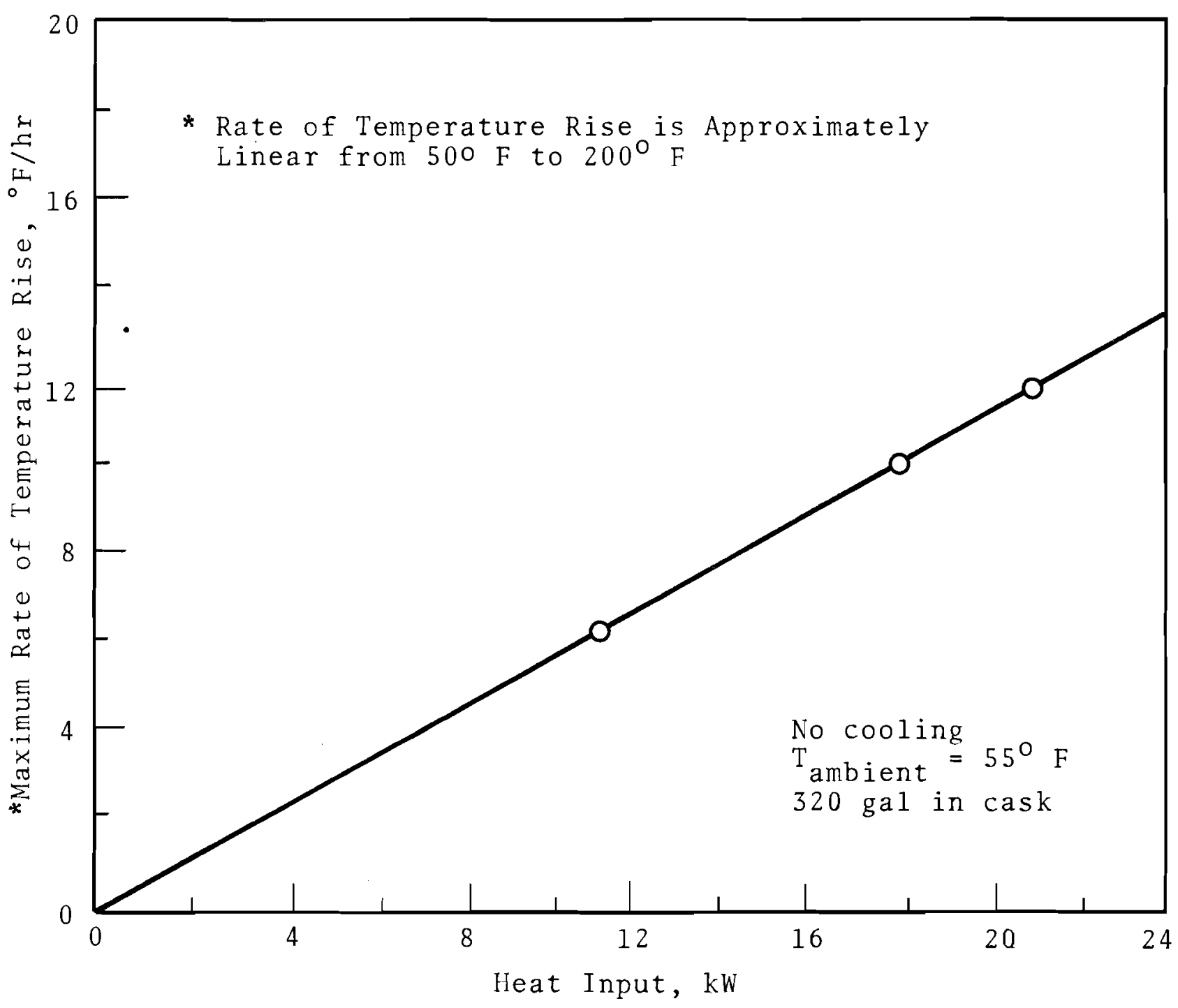

FIGURE 3. Initial Heating Rates for Uncooled 400 gal Cask 


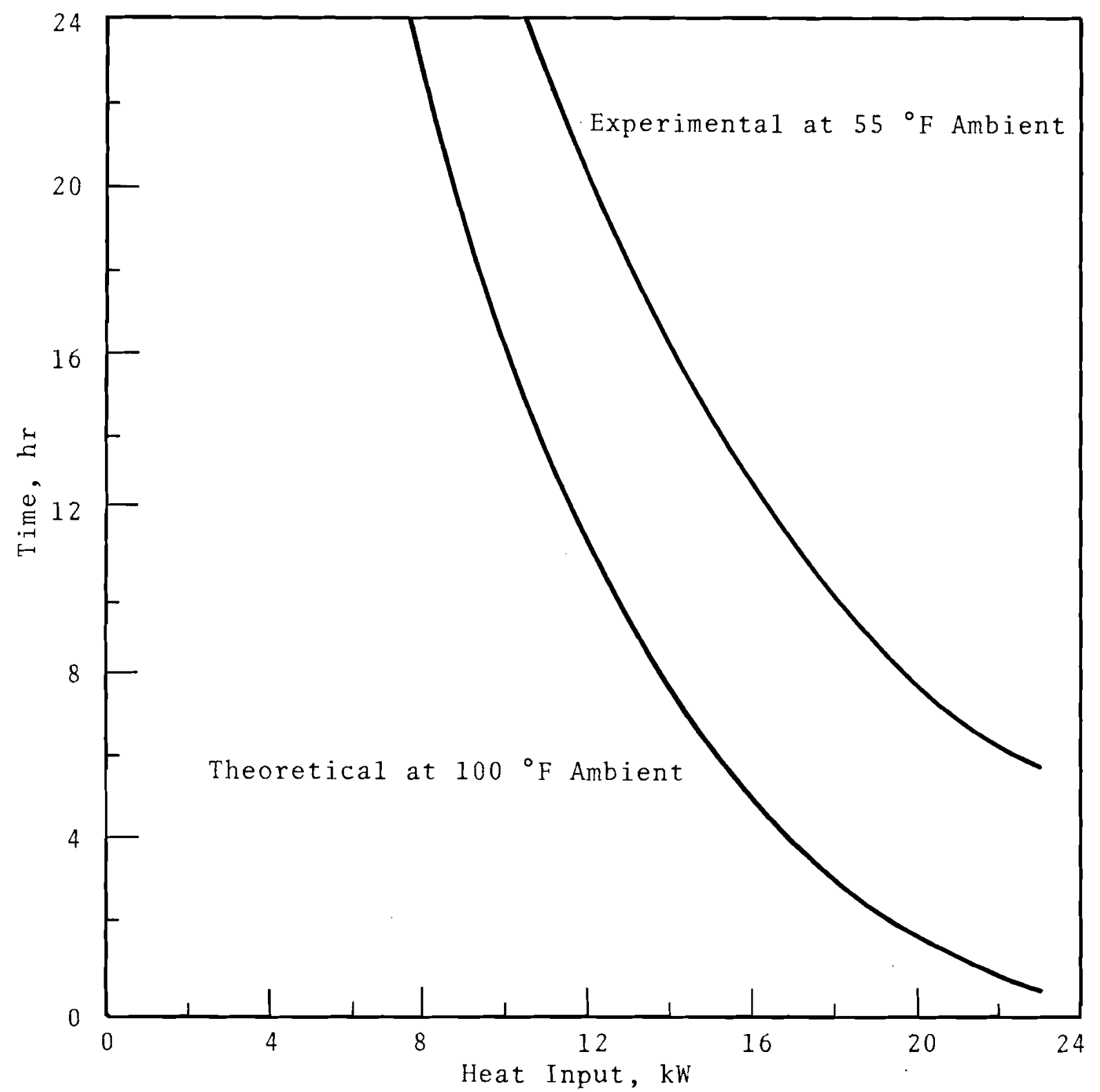

FIGURE 4. Time Required for Cask Contents to lleat from 125 to $200^{\circ} \mathrm{F}$ with No Cooling

Calibrations were made of the cask volumes using a capacitance probe and known incremental volumes of water. The results of the tests showed the cask cannot be overfilled under normal filling procedures, and the normal shipping volume of waste should be 320 gal. 
WSEP TRANSFER CASK INSTRUMENTATION - O. H. Koski

A new readout system was developed for use with capacitance probes to measure liquid level in waste casks. The integrated system, which uses capacitance to pulse height to DC conversion, was installed and calibrated in the $324 \mathrm{~B} 1 \mathrm{dg}$. This system does not require the careful installation and calibration of a conventional bridge-type capacitance system. The radiation exposed parts consist of the probe and probe head transformer, both of which can be made radiation resistant. External circuitry is all solid state with optional meter or potentiometric readout.

HAZARDS OF SHIPPING SOLIDIFIED HIGH LEVEL WASTE (A. E. Albrethsen and L. C. Schwendiman)

The maximum quantity of fission products that can be released to the airstream from a shipping accident involving high level radioactive waste and a high temperature fire is an important consideration in the overall evaluation of the accident. Experimental studies directed toward the evaluation of the high temperature fission product release from high level waste were continued. Two mechanisms of release are being studied, volatilization and mechanical entrainment of particles in the airstream.

The experiments are designed to measure the release of important fission products from ceramics simulating the product from high level waste solidification processes. In the experiments to be reported this quarter, portions of an actual high level waste phosphate glass were used as the trace material for the fission isotopes. A sample of this high level waste glass was ground to less than 100 mesh and aliquots of the powder blended with similarly prepared synthetic (non-radioactive) phosphate ceramic。 Resulting $15 \mathrm{~g}$ samples were gamma-counted for measuring the radioactive constituents present and placed in the metal 
crucibles for the release tests. This method of sample preparation is expected to produce a product representative of actual waste material because all of the constituents are in the same chemical form as the actual waste (either a phosphate glass or a micro-crystalline phosphate solid), the radioactive isotopes are in their proper proportions, and there is 1ittle chance for segregation of the dry blended constituents.

The fission product release heats are conducted in a controlled atmosphere induction furnace. Sweep gas and the released material are passed through a quartz chimney and any particles present are collected on a fiber glass filter. The filters, washings from the quartz chimney, and washings from other portions of the gas train are analyzed for the released isotopes.

Four release runs were made on one sample of PW-1 type ceramic, having a $M^{\top} / P$ of 2.5. The first run in which the powdered ceramic was fused consisted of slowly heating the sample up to $1100^{\circ} \mathrm{C}$ and then cooling. During the remaining heats the sample was rapidly heated to the goal temperature which was then maintained for two hours. The analysis of the principal radioactive isotopes is given in Table $I$; the release data are given in Table II; and the calculated hourly release rates are shown in Table III.

The cesium releases appear to be a little higher than expected from the previous release studies (BNWL-139, 170, 213). The ruthenium releases are considerably higher than expected from the previous studies. This could possibly be due to residual oxidants in the ceramic or to incomplete reduction of $\mathrm{RuO}_{4}$ during the solidification process. Residual volatiles were present as judged from the bubbling observed during the initial fusion. The influence of a highly reducing environment on ruthenium retention resulting from stainless steel 
TABLE I. Analysis of Principal Radiojsotope in Release

Sample $\mathrm{H}-1$ *

$$
\begin{array}{ll}
\mathrm{Cs}^{137} & 3.45 \times 10^{8} \mathrm{dpm} \\
\mathrm{Ru}^{106}-\mathrm{Rh}^{106} & 1.50 \times 10^{8} \mathrm{dpm} \\
\mathrm{Ce}^{144}-\mathrm{Pr}^{144} & 5.54 \times 10^{8} \mathrm{dpm} \\
\mathrm{Sr}^{90 * *} & 2.63 \times 10^{8} \mathrm{dpm} \\
\mathrm{Cs}^{134} & 1.34 \times 10^{7} \mathrm{dpm}
\end{array}
$$

* PW-1 type ceramic waste, $M+/ P=2.5$, nicke1 crucible. ** $\mathrm{Sr}^{90}$ calculated from $\mathrm{Cs}^{137}$ activity by using $\mathrm{Sr}^{90} / \mathrm{Cs}^{137}=0.763$

TABLE II. Release of Radioisotopes from Release Sample H-1*

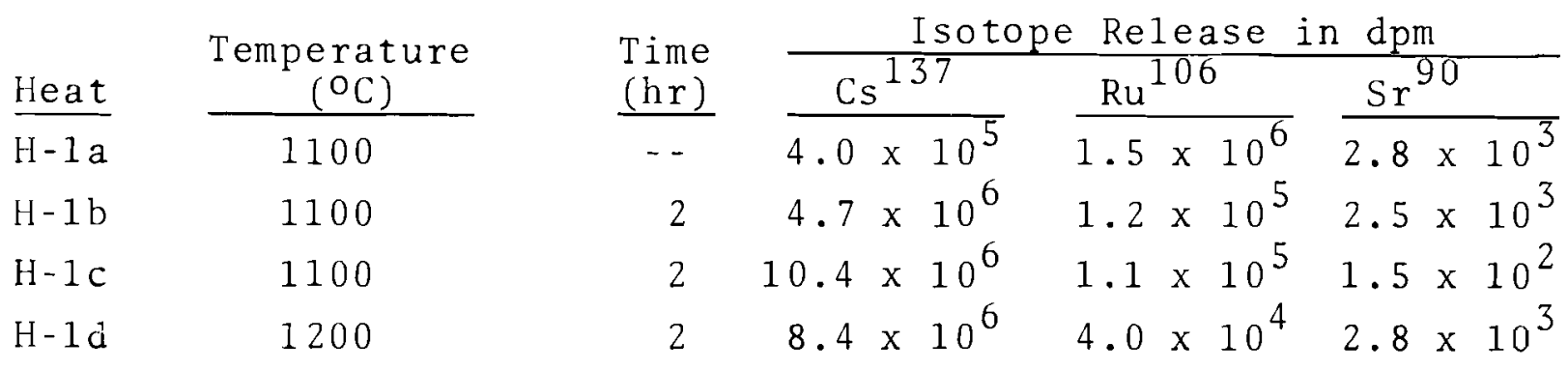

* PW- 1 type ceramic waste, $\mathrm{M}^{+} / \mathrm{P}=2.5$, nickel crucible

TABLE III. Fractional Release Rate from Radioisotope from Sample $\mathrm{H}-\mathrm{I}^{*}$

$\frac{\text { Heat }}{H-1 b}$
$H-1 c$
$H-1 d$

Release Rate for Isotope in Fraction/Hour

*PW-1 type ceramic waste, $\mathrm{M}^{+} / \mathrm{P}-2.5$, nickel crucible 
crucibles -- used in earlier studies -- is being evaluated. The $\mathrm{Sr}^{90}$ releases were consistent with the previous studies where releases of less than $10^{-5}$, the lower detection limit, were found.

\section{WASTE SOLIDIFICATION CONDENSATE TREATMENT}

$$
\text { (G. J.A1kire) }
$$

SCAVENGING MECHANISMS - C. J. Touhi11

A study of scavenging mechanisms was undertaken in order to eliminate some of the empiricism usually associated with precipitation reactions of this type. Experimentation was focused on the hydrous oxides and hydroxides since most scavengers fit into this category. A principal aim of the study is to uncover ways in which radioruthenium, which is often difficult to remove from radioactive effluents, can be more efficiently scavenged from solution.

Adsorption mechanisms on hydrous manganese dioxide were studied in the first phase of the investigation. Manganese dioxide was selected for several reasons. Hydrous manganese dioxide has been used as a radiochemical carrier and scavenger since the earliest studies of natural radioactivity, and in certain aspects it is a more versatile carrier than the hydrous oxides of either aluminum or ferric iron. In addition, it can be formed by a number of different chemical reactions and it has extremely low solubility in alkaline, neutral or strongly acidic solutions.

Ions appear to be sorbed by either ion exchange in the diffuse double layer of the colloid or by chemisorption, or by a combination of the two mechanisms. Both of these mechanisms are related to the degree of crystallinity. X-ray diffraction studies revealed that hydrous manganese dioxide formed by the Guyard reaction:

$$
3 \mathrm{Mn}^{+2}+2 \mathrm{MnO}_{4}^{-}+2 \mathrm{H}_{2} \mathrm{O} \rightarrow 5 \mathrm{MnO}_{2}+4 \mathrm{H}^{+}
$$


possesses a fairly consistent crystallinity pattern in widely varying hydrogen ion concentrations ( $\mathrm{pH} 1$ to 12). These patterns are shown in Figure 5 .

Electrokinetic studies showed that the adsorptive behavior of Guyard manganese dioxide is highly predictable. In conjunction with the $X$-ray diffraction studies, electrokinetic reversibility measurements yield evidence that the mechanism of adsorption is probably ion exchange in the diffuse double layer.

Manganese dioxide formed by the oxidation of a manganous salt by air in an alkaline environment does not exhibit a consistent crystalline structure over the same pH range (Figure 6). From a pH of 7.9 to 12 the colloid is readily identified. Below pH 7.9 the structure deteriorates to amorphousness until pH 6.8 where the pattern is rather diffuse.

This discontinuity drastically affects the scavenging behavior of the hydrous manganese dioxide. When electrokinetic measurements are used to supplement the $\mathrm{X}$-ray diffraction data, it appears that adsorption can be predicted by diffuse double layer model in the pll region from about 7.5 to 12 or slightly beyond. This model does not apply in the lower pH region, i.e. pH about 7.5 to 1. Electrokinetic reversibility measurements indicate that while there is some adsorption of the ion exchange type, chemisorption is probably the predominant mode of scavenging in the lower pH region. 


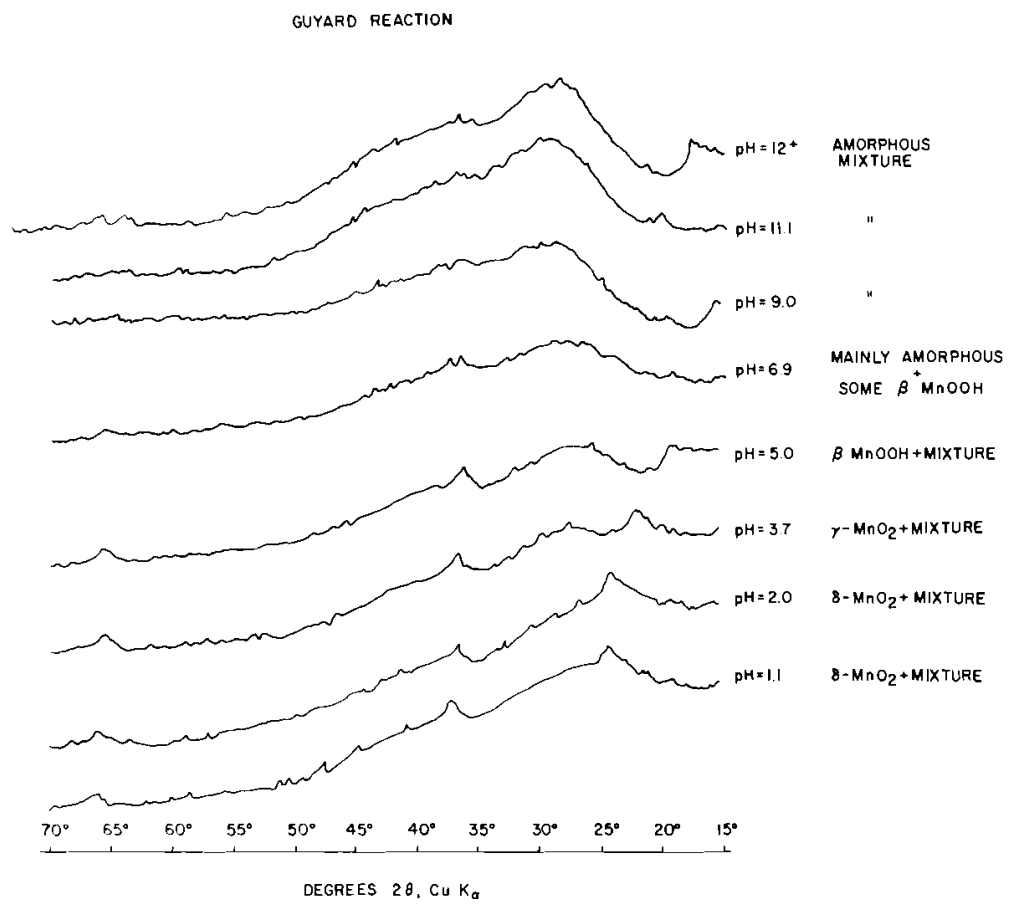

FIGURE 5. Guyard Reaction

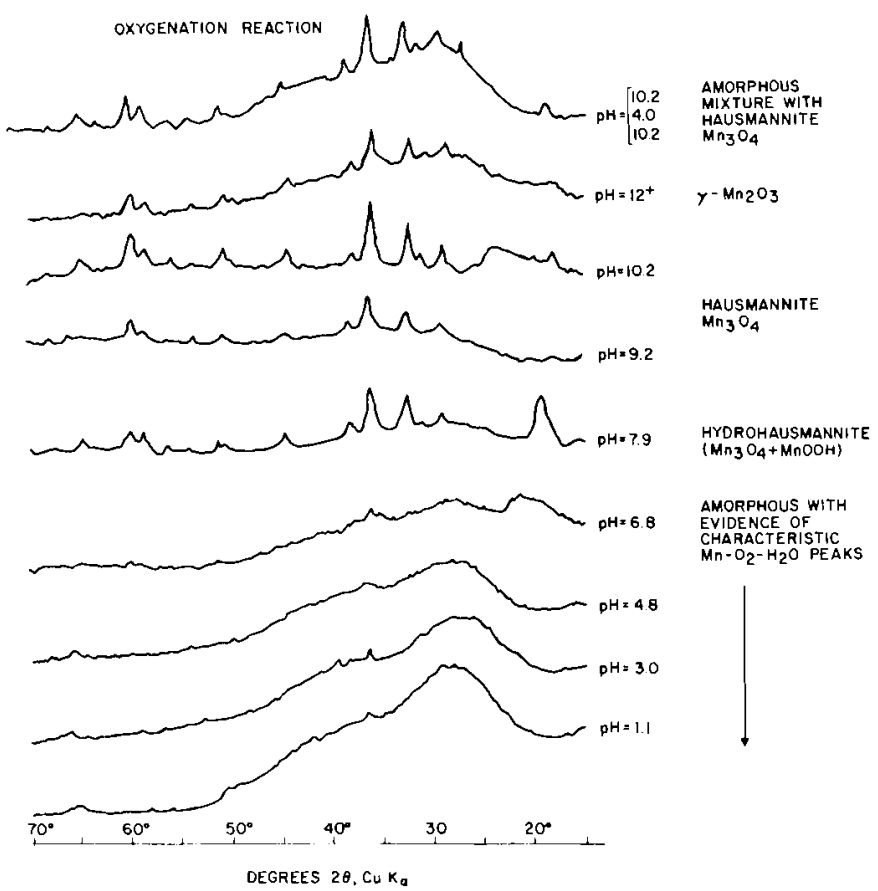

FIGURE 6. Oxygenation Reaction 
In preliminary experiments an attempt was made to correlate sorption on hydrous manganese dioxide and the mineral pyrolusite, which has a well defined crystalline structure. Pyrolusite column studies showed that radioruthenium in adjusted acid condensate waste $(\mathrm{pH}=5.1)$ is sorbed to less than $10 \%$ breakthrough at 400 column volumes and less than $20 \%$ breakthrough at 1250 column volumes. The results of acid elution studies show that for pyrolusite, radioruthenium removal is controlled by the chemisorption mechanism. Further studies will be undertaken to relate this behavior to that found for the hydrous manganese dioxide.

Additional experiments were designed to determine what factors influence chemisorption. Presumably, for chemisorption ions will be incorporated within the crystal microstructure of the central oxide particle. The two factors which were found to influence this incorporation most markedly were hydrated ion size and ionic charge.

Tracer level experiments were performed on manganese dioxide precipitates using $\mathrm{Cs}^{137}$ as the tracer and stable $\mathrm{Cs}^{+}$, $\mathrm{K}^{+}, \mathrm{Co}^{++}, \mathrm{Sr}^{++}, \mathrm{Ce}^{+++}$, and $\mathrm{Al}^{+++}$as the interfering ions. The degree of interference is shown in Table IV.

TABLE IV. Ion Interference with $\mathrm{Cs}^{137}$ Removal - Guyard Reaction at $\mathrm{pH}=3.3$

Percent Removal

\begin{tabular}{lcc} 
Ion & $10^{-3}$ moles/liter & $\frac{10^{-4} \text { moles/1iter }}{n}$ \\
\cline { 2 - 2 }${ }^{+}$ & 5.4 & 10.5 \\
$\mathrm{Cs}^{+}$ & 1.5 & 4.2 \\
$\mathrm{Co}^{++}$ & 6.0 & 12.2 \\
$\mathrm{Sr}^{++}$ & 7.4 & 11.7 \\
$\mathrm{Ce}^{++}$ & 1.4 & 2.3 \\
$\mathrm{Al}^{++}$ & 4.1 & 4.5
\end{tabular}


BNWL -267

The results showed that, in general, the higher valence ions interfered most, but ions with certain hydrated radii were able to interfere significantly due to radii which allowed migration closest to or within the crystal lattice. These findings were corroborated by reversibility studies which indicated that ions which interfered most were bound by the chemisorption mechanism.

The theory as developed thus far is presently being evaluated for practical cases, most notably for the scavenging alternative in the treatment of sulfate condensate wastes generated in the WSEP program.

SCAVENGING OF FISSION PRODUCTS - C. J. Touhill and J. E. Fager

Experimentation was undertaken to determine the degree of fission product scavenging by hydrous ferric oxide and by a mixture of hydrous ferric oxide and hydrous manganese dioxide from simulated glass melter condensate. The initial iron concentration in the simulated waste was $2 \times 10^{-3} \mathrm{M} \mathrm{Fe}^{+3}$. A comparison of the effectiveness of both methods, i. e. ferric oxide and mixed oxide scavenging, showed that $3 \times 10^{-2} \mathrm{M}$ of $\mathrm{Mn}^{+2}$ added to the simulated waste subsequent to precipitation at $\mathrm{pH}=10.0$ produced a more effective scavenger than an addition of $3 \times 10^{-2} \underline{\mathrm{M}}$ of $\mathrm{Fe}^{+3}$ subsequent to precipitation at $\mathrm{pH}=10.0$.

Strontium, cesium, and cobalt removal was about equal for both scavengers. However, the mixed oxide system was 10 to $15 \%$ more effective in scavenging ruthenium and cerium. Hence, the mixed oxide system with an addition of $3 \times 10^{-2} \mathrm{M} \mathrm{Mn}^{+2}$ was selected for further experimentation. Table $V$ shows the removal of certain radionuclides which was obtained by this system. 
TABLE V. Radionuclide Removal Efficiencies Using a Mixed Oxide Scavenger

\begin{tabular}{|c|c|c|}
\hline Radionuclide & $\begin{array}{l}\mathrm{pH} \text { Range for } \\
\text { Optimum Removal }\end{array}$ & $\begin{array}{l}\text { Maximum } \\
\text { Removal }\left(\frac{\%}{0}\right)\end{array}$ \\
\hline $\mathrm{Ru}^{106^{*}}$ & $7.7-10.5$ & 98.7 \\
\hline$C e^{144}$ & $5.0-12^{+}$ & 99.5 \\
\hline $\mathrm{Cs}^{137}$ & - & $<10$ \\
\hline $\mathrm{Sr}^{85}$ & $9.5-12.0$ & 98.5 \\
\hline $\mathrm{Co}^{60}$ & $10.5-12.0$ & 99.5 \\
\hline
\end{tabular}

* Ru 106 tracer was pretreated to approximate the nitrosylruthenium species.

Since cesium removals were unsatisfactory, various ferricyanide precipitates were used to remove cesium. In these experments the precipitation of ferricyanide was effected concurrently with the mixed oxide scavenging. The cations used for ferricyanide precipitation were: cerium, cobalt, copper, nickel, and zinc. Table VI shows the results obtained for cesium removal as the ferricyanide. The $\mathrm{pH}$ of the final solution was 10 , and the $\mathrm{K}_{3} \mathrm{Fe}(\mathrm{CN})_{6}$

TABLE VI. Cesium Removal by Ferricyanide Precipitation

$$
\begin{array}{cc}
\text { Metallic Ion } & \text { Cs Removal }\left(\frac{0}{0}\right) \\
\hline \mathrm{Ce}^{+++} & 95.2 \\
\mathrm{Co}^{++} & 99.6 \\
\mathrm{Cu}^{++} & 94.6 \\
\mathrm{Ni}^{++} & 99.9 \\
\mathrm{Zn}^{++} & 98.5
\end{array}
$$

and metallic ion concentrations were $0.004 \underline{M}$. The nickel ferricyanide was selected for further experimentation for scavenging optimization. 
CRYSTALLIZATION OF SODIUM SULFATE - B. W. Mercer, C. J. Svoboda Crystallization of sodium sulfate at temperatures near $100^{\circ} \mathrm{C}$ from partially neutralized, simulated glass melter condensate was investigated. A $50 \%$ solution of sodium hydroxide was added to the simulated condensate $\left(4.4 \mathrm{M} \mathrm{H}_{2} \mathrm{SO}_{4}, 5.3 \mathrm{M} \mathrm{HNO}_{3}\right.$, and $0.18 \quad \mathrm{M}_{3} \mathrm{PO}_{4}$ ) in the stoichiometric amount to react with the sulfuric acid. A portion of the partially neutralized condensate was evaporated by boiling to half its original volume. The sodium sulfate crystals were filtered and washed with a portion of the partially neutralized condensate. The filtrate and washes were recycled to the partially neutralized condensate. This crystallization and wash procedure was repeated six times. Analytical results with $\mathrm{Sr}^{85}$ tracer indicate that only half of the strontium separated from the sodium sulfate. Substitution of small volume water washes in place of the condensate washes did not improve strontium separation.

WASTE MANAGEMENT

(Not charged to the Division of Reactor Development and Technology) IN TANK WASTE SOLIDIFICATION - J。 Dunn, E. E. Hoar

The prototype immersion heated circulator being tested under plant conditions became plugged with a crystalline deposit, and 10 of the 12 electric heaters failed. Preliminary analysis attributes the malfunction to buildup of sludge in the tank, to a depth sufficient to block circulation during an earlier shutdown to repair the off-gas filters. An investigation of the problem is now underway, emphasizing the development of flow detection instrumentation. In addition to a dip tube flow monitor which will indicate pressure differential due to velocity head, a strain gauge beam deflection flow meter has been designed and fabricated. Also under study is a heated thermistor whose temperature will be a function of ambient flow velocity. A 
transparent circulator model has been installed for evaluation of these devices and also for determining conditions for maintaining or re-instituting circulation in the presence of simulated sludge.

Topical Reports Issued

Testing of Immersion Heaters for In-Tank Solidification Circulators, J. Dunn, BNW-101.

Jet Pump Tests for Concentrated Waste Transfer, J. Dunn, BNWL - CC -395 .

TEMPERATURE IN UNDERGROUND WASTE STORAGE TANKS - W. E. Willingham

The final report in this series has been completed. It summarizes the previous work on the subject and presents a generalized correlation for the effect of tank size, height and spacing, soil cover depth, water table depth and thermal properties of the system.

The empirical correlation resulted in an equation of the following form:

$$
\left.\mathrm{k}_{\mathrm{s}} \frac{\left(\mathrm{T}_{\left.\mathrm{MAX}^{-\mathrm{T}_{\mathrm{A}}}\right)}^{\mathrm{S} \ell_{\mathrm{C}}{ }^{2}}\right.}{\mathrm{s}_{\mathrm{c}}}\right)^{(.04}\left(\frac{\mathrm{k}_{\mathrm{s}}}{\mathrm{k}_{\mathrm{c}}}\right)^{-0.22}\left(\frac{\ell_{1}}{\ell_{\mathrm{c}}}\right)^{+0.88}
$$

or rewriting it

$$
\mathrm{T}_{\mathrm{MAX}}{ }^{-\mathrm{T}_{\mathrm{A}}}=1.04 \mathrm{~s} \mathrm{k}_{\mathrm{s}}^{-0.78} \mathrm{k}_{\mathrm{c}}^{-0.22} \ell_{\mathrm{c}} 1.22 \ell_{1} 0.88
$$

From this it can be seen that the maximum temperature is a strong function of the soil thermal conductivity and a weak function of the cake thermal conductivity, while cake thickness and soil cover depth have little effect. The standard deviation for a least squares fit of the computer results to the above equation is $+8.6 \%$ to $-7.9 \%$.

Two additional documents on the subject have been completed - BNWL-181 (Feb. 1966) "Buried Radioactive Waste Storage 
Tank Temperatures and Soil Temperatures Near Leaks", G. Jansen, W. E。 Willingham, and W. V. DeMier; and BNWL-SA-468 (Feb. 1966) "Heat Transfer in Underground Tank Storage of Radioactive Wastes", G. Jansen, W. E. Willingham, and W. V. DeMier, which was presented at the Symposium on the Solidification and Long Term Storage of Highly Radioactive Wastes, Richland, Washington, February 14-18, 1966.

RESIDUAL SLUDGE DETECTOR FOR WASTE STORAGE TANKS - C. E. Huck

A collimated, scintillation gamma photon transducer was developed and tested using a $1 / 2 \mathrm{~g}$ radium sulfide source. Readings were taken with the scintillation head unit assembled to its associated 3/16 ID lead collimator head. Dose rates at the scintillation crystal were varied by mechanically positioning the $\gamma$ source at different distances from the transducer. Readings varied from $5200 \mathrm{CPM}$ at $7.7 \mathrm{mr} / \mathrm{hr}$ to $33,500 \mathrm{CPM}$ at $50 \mathrm{mr} / \mathrm{hr}$. These readings indicate that this prototype system should properly show sludge deposits in waste tanks provided gamma emitter concentrations in the supernate and sludge are the same as the values initially provided to $B N W$ by Isochem. Expected values at the detector head based on calculations are about $10 \mathrm{mr} / \mathrm{hr}$ when viewing sludge and 0.1 to $1.0 \mathrm{mr} / \mathrm{hr}$ when viewing supernate. STRONTIUM AND RARE EARTH RECOVERY FROM ZIRFLEX WASTE G. L. Richardson

Pulse column studies with D2EHPA solvent in support of Isochem's Waste Management Program demonstrated quantitative extraction of strontium and rare earths from a synthetic zirflex-type Purex High-level waste. The flowsheet differed from that studied previously ${ }^{(1)}$ in having two- to three-fold more iron and eight-fold more aluminum in the feed. Both tartaric acid and HEDTA at 10 to $20 \%$ excess were tested as complexing agents for the iron and aluminum. The HEDTA, as expected, proved to be more effective in preventing the extraction of these 
impurities; but even with HEDTA, approximately 0.6 to $1 \%$ of the aluminum in the feed was found in the rare earth product. The corresponding contamination from the tartrate feed was about three-fold greater. Although the iron extracted at about the same rate as the aluminum, the contamination in the product streams was generally less than $0.02 \%$ with both feeds.

CESIUM ION EXCHANGE RESIN LEVEL MEASUREMENT - O. H. Koski

Two techniques for measuring ion exchange resin level are being developed. One system, identified as the incremental conductivity system, indicates both liquid and resin levels from conductivity measurements performed on an increment of resin column depth. Successive increments of three inches over a fourteen foot span are scanned with a simultaneous recorder readout of both increment location and conductivity.

The other system is based on adaptation of a commercially available ultrasonic testing device. In its operation, a submerged transducer generates an ultrasonic wave which is reflected from the resin surface. The time from the echo to a selected time marker is used as a measure of resin depth. Time corrected gain, material calibration delay adjustments and gain adjustments make possible the rejection of unwanted reflections from supporting hardware and air bubbles on the transducer face.

(1) G. L. Richardson, "Solvent Extraction of Strontium, Cerium, and Rare Earths with D2EHPA, Part 2: Pilot P1ant Studies", HW-79762, Pt. 2, February, 1964. 
DISTRIBUTION

No. of Copies

3

1

6

3

1

1

2

1

1
Atomic Energy of Canada Limited

C. A. Maws on

I. L. Ophe1

L. C. Watson

AEC, Sydney, Australia

R. C. P. Cairns

Atomic Energy Commission, Washington

W. G. Belter, Division of Reactor Development (3)

R. S. Brodsky, Division of Nava 1 Reactors (1)

W. L. Lennemann, Division of Production (1)

F. C. Schwenk, Space Nuclear Propulsion Office (1)

Atomic Energy Research Establishment Harwell, Didcot, Berks, England

R. H. Burns

W. H. Hardwick

K. D. B. Johnson

Australian Atomic Energy Commission

Research Establishment

Private Mail Bag

Sutherland, New South Wales, Australia

M. G. Bailie, Chemical Engineering Section

N. V. Belchim

200 Boeretang

Mo1, Be1gium

Leo. H. Baetsle

Brookhaven National Laboratory

L. P. Hatch

E. J. Tuthill

Bureau of Mines, Bartlesville

J. W. Watkins

Center for Nuclear Studies

P. 0. Box 6, Fontenay-aux-Roses

(Seine), France

J. Pomerola 


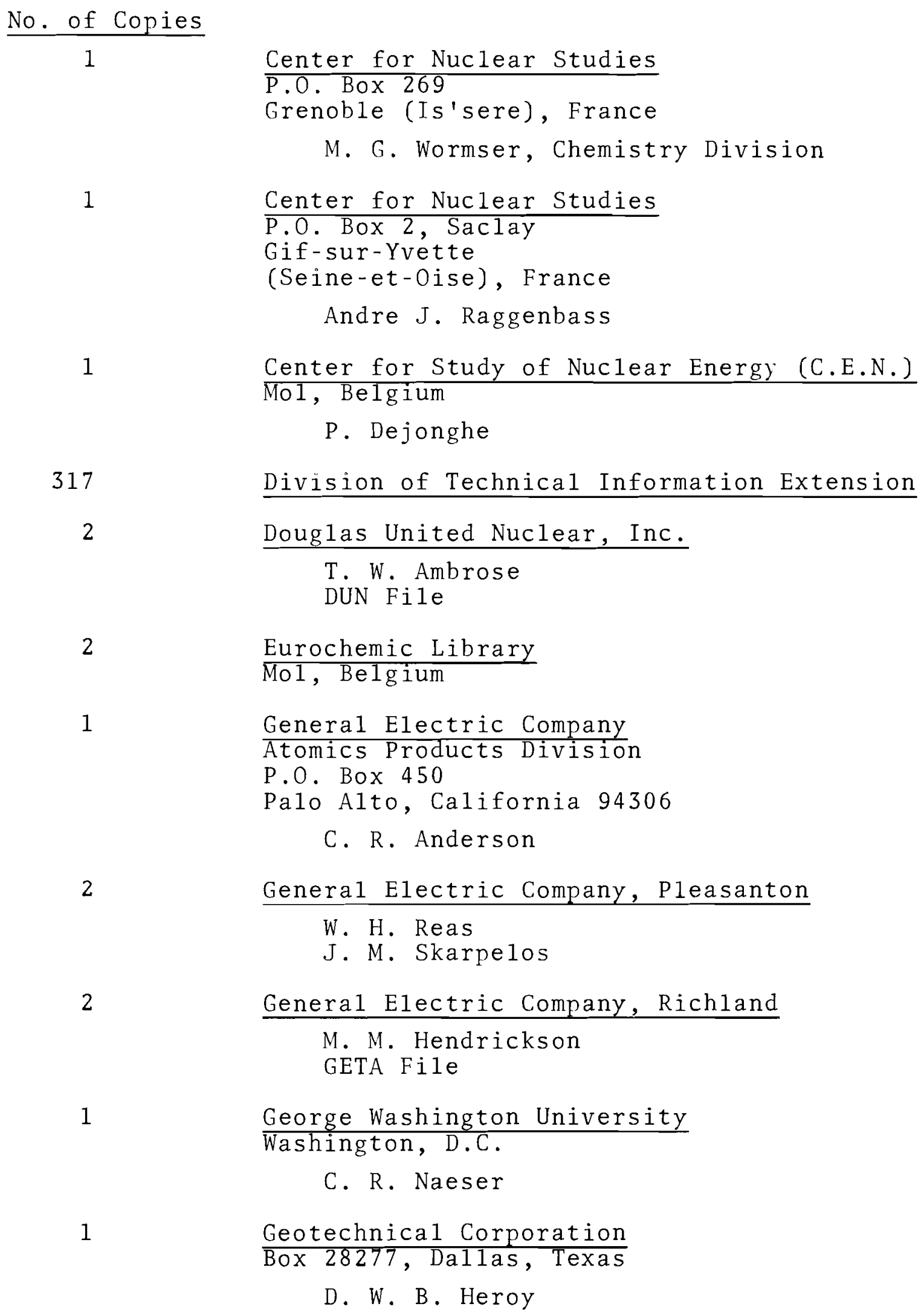

General Electric Company, Richland

M. M. Hendrickson

GETA File

George Washington University Washington, D.C.

C. R. Naeser

Geotechnica1 Corporation

Box 28277, Dallas, Texas

D. W. B. Heroy 
No. of Copies

1

1

2

1

13

1
Gessellschaft fur Kernforschung mbH Weberstr. 5

Karlsruhe, Germany

Dr. H. Krause, Chief Research Group

W. R. Grace \& Company

I01 N. Charles Street

Baltimore, Maryland 21203

R. P. Wischow, Nuclear Chemistry

Division

India Atomic Energy Establishment

Trombay Engineering Hall No. 5

Bombay 73, India

Jitender D. Seha 1

Keshava Chandra

International Atomic Energy Agency

Vienna 1, Kaerntnerring, Austria

C. W. Christenson

Isochem Inc.

0 . F. Beaulieu

J. B. Fecht

W. M. Harty

O. F. Hill

H. H. Hopkins

L. M. Knights/S. J. Beard

W. P. McCue

H. P. Shaw

R. J. Sloat

R. E. Smith

R. E. Tomlinson

J. H. Warren

File Copy

Johns Hopkins University

Baltimore, Maryland 21218

W. A. Patrick

MPR Associates, Inc.

815 Connecticut Avenue., NW

Washington, D.C. 20006

Theodore Rockwell, III, Chairman, AIF Safety Task Force 


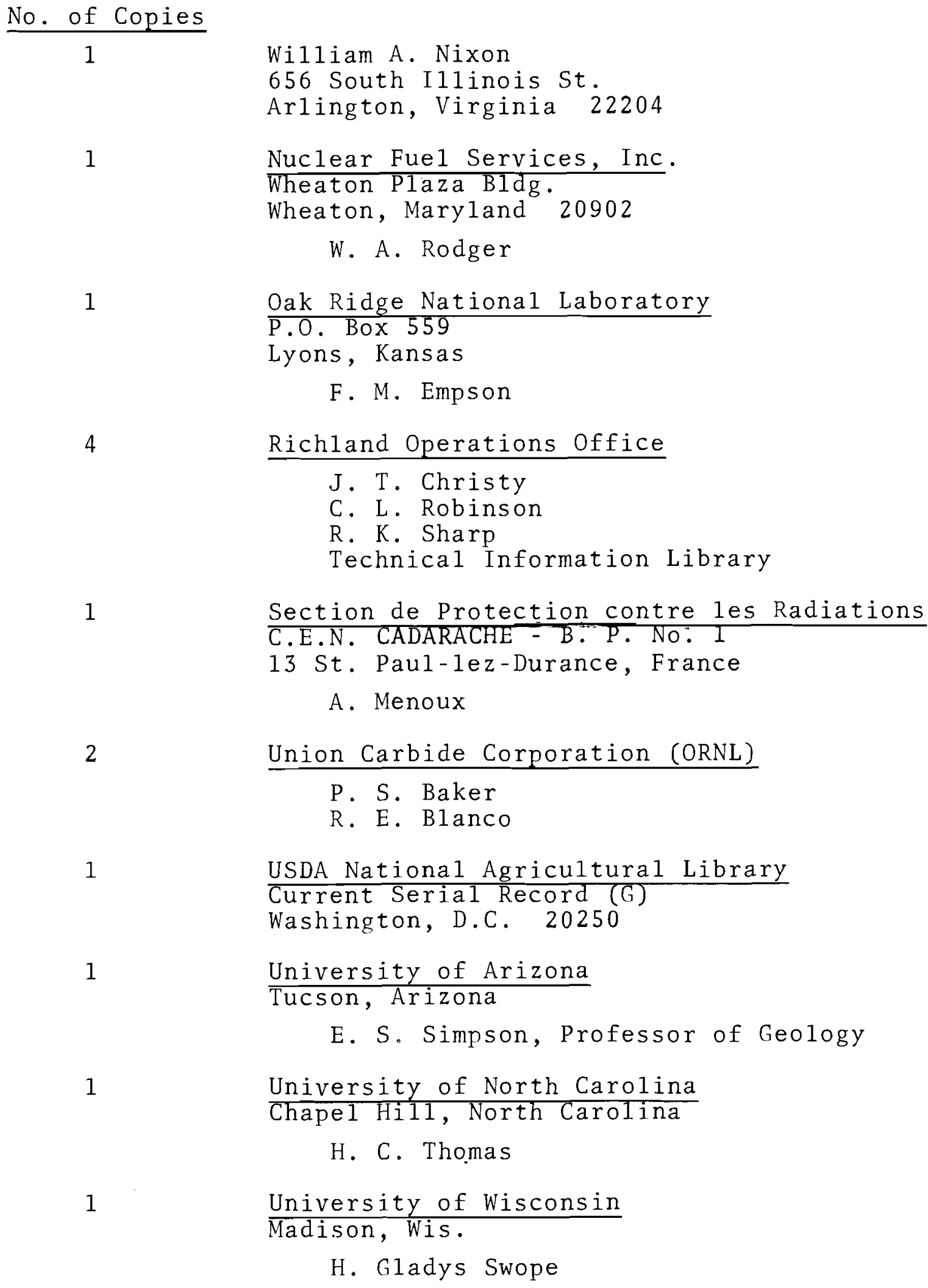

USDA National Agricultural Library

Current Serial Record (G)

Washington, D.C. 20250

1

University of Arizona

Tucson, Arizona

E. S. Simpson, Professor of Geology

1

University of North Carolina

Chapel Hill, North Carolina

H. C. Thomas

University of Wisconsin

H. Gladys Swope 
No. of Copies

A. E. Albrethsen

G. J. Alkire

L. L. Ames

J. M. Atwood

G. B. Barton

R. E. Brown

R. E. Burns

C. R. Cooley

G. M. Dalen

W. V. DeMier

W. A. Haney

E. R. Irish

B. M. Johnson

R. L. Junkins

J. D. Kaser

A. R. Keene

C. E. King

H. A. Kornberg

R. L. Moore

H. M. Parker

D. W. Pearce

A. M. Platt (2)

G. Rey

K. J. Schneider

L. C. Schwendiman

M. E. Spaeth

W. H. Swift

U. L. Upson

E. E. Voiland

M. T. Walling

F. W. Woodfield

Technical Information Files (5)

Technica1 Publications (2) 